torially lucid as to the meaning of the terms involved.

Let $A, B, C$, be the principal axes of inertia and $\omega_{1}, \omega_{2}, \omega_{3}$, the angular velocities of the rigid body around them. All this is kinematic.

Let $A^{\prime}, B^{\prime}, C^{\prime}$, be the positions of these axes a unit of time later. Lay off the angular momenta, $A \omega_{1}, B \omega_{2}, C \omega_{3}$, along these axes in order, as shown. Then will $A A^{\prime}, B B^{\prime}, C C^{\prime}$, be the corresponding per second changes of angular momentum.

Resolve each of these into components parallel to the original axes, and bring those belonging to the same axis together, viz.,

$$
\begin{array}{lll}
-B \omega_{2} \cdot \omega_{3}, & -C \omega_{3} \cdot \omega_{1}, & -A \omega_{1} \cdot \omega_{2}, \\
+C \omega_{3} \cdot \omega_{2}, & +A \omega_{1} \cdot \omega_{3}, & +B \omega_{2} \cdot \omega_{1},
\end{array}
$$

remembering that as each axis rotates about the other two, the component displacements per second will be

$$
\omega_{2}, \omega_{3} ; \omega_{3}, \omega_{1} ; \omega_{1}, \omega_{2} .
$$

Add to the component changes of momentum found, the direct per second changes of angular momentum around the respective axes, viz.,

$$
+A \dot{\omega}_{1}, \quad+B \dot{\omega}_{2}, \quad+C \dot{\omega}_{3} \text {. }
$$

Let $L, M, N$, be the torques around the three axes in order, and equate these to the total per second change of angular momentum corresponding to the same axes. In other words, after adding each of the three columns,

$$
\begin{aligned}
& L=A \dot{\omega_{1}}-(B-C) \omega_{2} \omega_{3}, \\
& M=B \dot{\omega_{2}}-(C-A) \omega_{3} \omega_{1}, \\
& N=C \dot{\omega_{3}}-(A-B) \omega_{1} \omega_{2} .
\end{aligned}
$$

C. Barus.

\section{ON A CRINOIDAL HORIZON IN THE UPPER} CARBONIFEROUS.

For more than half a century the Lower Carboniferous limestones of the Mississippi valley have been justly celebrated for their enormous wealth of crinoidal remains. On this account, they have become widely designated as Encrinital limestones, a title which has long since assumed a distinctive value.

The crinoidal element in the faunas of the Lower Carboniferous has been further emphasized by the apparent extreme paucity or entire absence of crinoid remains in all other parts of the Carboniferous section of the region. The few species described were few in number, from widely separated localities and from very fragmentary material.

Unusual interest was, therefore, aroused a few years ago by the discovery, in the Upper Carboniferous rocks of the Missouri river, of a formation so rich in fossil crinoids as to merit the title Encrinital as appropriately as any terrane of the Lower Carboniferous. Species were not only new and numerous, but individuals occurred in the utmost profusion, their stems and long, slender, beautifully pinnulated arms intertwining as intricately as the richest of flowing arabesques. Moreover, the state of preservation was wondrously perfect. From a morphological standpoint the discovery was one of the most important ever made.

The geological position of this rich crinoid fauna is a short distance above what is called the Lower Coal Measures. It is in the terrane now known as the Thayer shales, the base of which is a stratigraphic level not much over 600 feet above the Lower Carboniferous limestones. The Thayer shales are in the lower part of the Missourian series. They are dark blue in color, and lithologically are indistinguishable from the Crawfordsville Shales of Indiana, which have been so prolific in crinoids in fine state of preservation.

The biological peculiarities of the crinoids from the Thayer shales as compared with those of the nearest forms from the Lower Carboniferous are noteworthy features. For two faunas so closely connected in space the differences are so profound when apposed to the resemblances as to be almost inexplicable.

But a satisfactory solution of the remarkable problem has been lately supplied from a source other than the biotic. The recently workedout stratigraphy of the region throws light upon it in an unsuspected manner. The actual position of the Thayer shales, instead of being re moved only 600 feet from the Lower Carboniferous limestones, are, stratigraphically, thousands of feet away.

While the lower coal measures have long. been known to rest unconformably upon the underlying rocks, the stratigraphic break has been regarded as merely local in nature. of late, the real significance of this hiatus has been 
adjudged. A depositional equivalent has been found in a neighboring State. In central Arkansas, the unconformity is now discovered to be represented by no less than 20,000 feet of sediments. The real values of the new relationships of the horizons are better shown by a rectified general geological section of the Carboniferous of the region.

WESTERN INTERIOR SECTION.

\begin{tabular}{l|l|r}
\hline \multicolumn{1}{c|}{ Series. } & \multicolumn{1}{c|}{ Terrane. } & Thickness. \\
\cline { 2 - 3 } Oklahoman. & Not here differentiated. & 1,500 \\
\cline { 2 - 3 } & Cottonwood limestone. & 10 \\
& Atchison shales. & 500 \\
& Forbes limestones. & 25 \\
& Platte shales. & 105 \\
Missourian. & Plattsmouth limestones. & 30 \\
& Lawrence shales. & 265 \\
& Stanton limestones. & 35 \\
& Parkville shales. & 75 \\
& Tola limestone. & 30 \\
& Thayer shales. & 50 \\
Des Moines. & Bethany limestones. & 75 \\
\cline { 3 - 3 } & Marais des Cygnes shales. & 250 \\
& Henrietta limestones. & 50 \\
Arkansan. & Cherokee shales. & 200 \\
\cline { 3 - 3 } Miscissippian. & Not here differentiated. & 20,000 \\
\cline { 2 - 3 } & Not here differentiated. & 1,500 \\
\hline
\end{tabular}

Of these five series of the Carboniferous system, the Oklahoman represents the so-called Permian; the next three the coal measures; and the Mississippian the Lower Carboniferous. Measured in sediments, the horizon of the Thayer crinoids is far up in the Carboniferous, instead of being near the base. At Kansas City, where the crinoids were found, the Arkansan is represented by the hiatus-a period of vast erosion in that locality.

\section{Charles R. Keyes.}

THE PROCESS OF FREEZING IN PLANTS.

IN text-books on plant physiology, and in original articles upon the effects of freezing in plants, or on allied subjects, so far as is known to the writer, there is no working explanation of the process. The matter is referred to by Detmer and Moor, Vines, Haberlandt, Sorauer, Sachs and many others, but without detailed explanation.

The cells bounding the intercellular'spaces (in leaves) are always moist on the side in con- tact with the air. As cooling goes on, all the tissue, contents of the cells and all, are contracting; but when a temperature of about $4^{\circ} \mathrm{C}$. is reached, the water content of the cell begins to expand, while the wall goes on contracting. This forces more moisture into the intercellular spaces. When the freezing point for water is reached, ice crystals begin to form outside of the cell in the intercellular spaces. The ice crystals will form first here, because water has a higher freezing point than the solution within the cell. As cooling goes on, and further crystallization takes place, the freezing water gives off its latent heat which tends to keep, for a considerable time, the cell contents from freezing. The crystallizing water without the cell extracts water from the cell by an inherent at. tractive force which the molecules of the mother crystal have for its liquid. This force is the cause of further water being drawn from the cell to build up the crystal of ice, and this attractive force is a similar one to that which causes plasmolysis in the case of the common experiment with cells of Spirogyra and a solution of sodium ehloride. The ice forms first in the intercellular spaces and continues to form there until the cell contents become frozen.

If a leaf so frozen be subjected to a higher temperature, water will be formed in the intercellular spaces, resulting in a translucent, ' waterlogged' appearance of the tissue of the leaf. If, however, the temperature be raised very gradually, the cells will probably resorb the extracted water as rapidly as it is formed, resulting in no permanent injury to the leaf. Sachs found that the leaves of the beet and the cabbage frozen at from $-4^{\circ} \mathrm{C}$. to $-6^{\circ} \mathrm{C}$, and thawed in air at 2 to $3^{\circ} \mathrm{C}$., were killed, while when thawed slowly in water at $0^{\circ} \mathrm{C}$. they sur. vived.

If the temperature be low enough and be continued long enough a permanent injury would result, for then the cell. contents would become solidified.

In the case of the experiment with a beet partially scooped out and subjected to a freezing temperature, the formation of ice in the cavity is brought about in exactly the same way as it is in the intercellular spaces in leaves of plants, excepting on a larger scale. If the 